Marta S Ljubisavljević ${ }^{1}$

Slavoljub R Živanović ${ }^{2}$

\footnotetext{
${ }^{1}$ Health care center "Milutin Ivković" Palilula, Beograd

${ }^{2}$ City Institute Emergency medical service Belgrade Serbia
}

\title{
Self-reported allergy to parenterally administered penicillin
}

\section{Summary}

Introduction: Penicillin and penicillin products are in use in everyday medical practice. The most frequently reported adverse drug reactions are those to penicillin. New penicillin allergies occur more often with parenteral than oral treatment. In patients who are allergic to penicillin, prescribed therapy is more often the one of antibiotics of broad spectrum, and this therapy is more expensive. The allergies to penicillin are immunologically mediated.

Scope of Study: to present patients' self-reported allergy to penicillin and report on types of adverse reactions following the parenteral administration of penicillin.

Methodology: Retrospective study of the work of one physician in the City Institute for EMS Belgrade in the period from 2017 to 2018 involving 2481 patients.

Results : There were 242 patients who reported they were allergic to penicillin, of which 160 were able to explain what happened after they were given parenteral penicillin. The cohort group was between 18-85 years old, average age $49.64 \pm$ 17.24 , while $65 \%$ of them were females. Most frequently reported adverse reactions were rash, redness and itching of the skin, loss of consciousness, swelling of the face, mouth, arms or body in general. Serious reactions have been reported in about $40 \%$ of cases

Conclusion: There is a large percentage of self-reported allergies to penicillin, and only a small number of those who experienced serious adverse reactions: swelling, unconsciousness, coma or shock.

Key words: Primary health care, penicillin allergy, parenteral penicillin, parenteral administration, emergency medical service 


\section{Introduction:}

Penicillin and penicillin products are in use in everyday medical practice. The most frequently reported adverse drug reactions are those to penicillin(1).

When patient states that he is allergic to penicillin, this means that in his therapy we cannot include drugs from this group because the patient would be placed under health risks and this could endanger his life. In such cases, the use of cephalosporins is also questionable because of crossreactivity. Cross-reactivity exists between penicillin and the first generation of cephalosporins, with a risk of $0.5 \%$, but there is no evidence of cross-reactivity for most cephalosporins of the second and third generation $(2,3)$. Depending on the research, in subjects with a documented IgE-mediated hypersensitivity to penicillin, a rate of positive responses to allergy tests with cephalosporins ranging from $0 \%$ to $27 \%$ have been found(4). "Penicillin allergy is often diagnosed early in life, and the history of penicillin allergy persists in a patient's medical record for many years without verification. Some physicians' consideration of a patient having penicillin allergy is based on patient experience that may have occurred early in childhood"(5). Penicillin allergy remains the most common drug allergy reported, with a prevalence of $\sim 8-12 \%$ depending on the specific population evaluated, and in the USA there is a reported prevalence of $10 \%(6)$. In the research conducted in Boston, USA, " 35.5\% of patients had at least one reported drug allergy with an average of 1.95 drug allergies per patient. The most commonly reported drug allergies in this population were to penicillin (12.8\%)"(7). Allergic reactions to penicillin occur in about $0.4-5 \%$ of patients and can be fatal in $0.002 \%$ patients(8). In Vićentijevic's research the most frequent allergies are to penicillin with $46 \%$ of patients reporting allergies to drugs(9) or in Dmitrović $\mathrm{R}$. and Zivanovic S.(10) research $56.13 \%$ of patients are reporting allergies to drugs.

"New penicillin allergies were reported more commonly after parenteral $(0.85 \%)$ compared with oral $(0.74 \%)$ exposures. Only 1 of $1543(0.065 \%)$ oral and 1 of 1030 $(0.097 \%)$ parenteral penicillin-associated allergy reports were confirmed to be anaphylaxis"(11)

Patients allergic to penicillin use more of wide-spectrum antibiotics, more fluoroquinolones, and have a higher estimated Clostridium difficile risk(12). Treatment of patients allergic to penicillin with a wide spectrum of antibiotics leads to multiple side effects, higher costs and the creation of multi-resistant strains(13). "In patients with an allergy to penicillin documented in their medical records the total number of prescriptions increases. "Total number of prescriptions were increased in patients with a PenA record. PenA records are common in the general population and associated with increased/altered antibiotic prescribing and worse health outcomes"(14). "Prevalence of Pen-A registration in hospitalized patients is high, has high impact on antibiotic prescribing, and is associated with a higher risk of readmission. Verification of the PenA in hospitalized patients might restrict the use of reserve antibiotics and improve patient outcome"(15). In literature, manifestations that are reported as allergic reactions to penicillin are listed according to frequency: rash, unknown/undocumented, hives, swelling/angioedema, anaphylaxis, as well as itching, dyspnea, nausea/ vomiting, diarrhea, palpitations, headache and ocular toxicity. According to the $\mathrm{CDC}$, the following symptoms can be classified as IgE-mediated reaction to penicillin: reactions that occur immediately or 
usually within one hour, hives, angioedema, wheezing and difficulty breathing, symptoms and signs of anaphylactic reactions affecting at least two of the following systems - Skin: hives, redness, itch and/or angioedema; Respiratory: cough, congestion, difficulty breathing, chest tightness, wheezing, constriction of airways/closing of the throat, change in voice quality; Cardiovascular: hypotension, tachycardia or less frequently bradycardia, tunnel vision, chest pain, sense of imminent death, loss of consciousness; Gastrointestinal: nausea, vomiting, stomach cramps, diarrhoea(16).

\section{Scope:}

The scope of study was to evaluate patients' statements on adverse reactions they experienced after receiving parenteral penicillin and what was later diagnosed as a true allergic reaction.

\section{Methodology:}

The study is a cross-sectional study, a retrospective analysis of the work of one doctor in the City Institute for EMS Belgrade from 27.07 .2017 to 28.122018 on a total of 2481 patients.

When a patient contacts our call centre, we start a paper protocol and an electronic form in MS Access database which is later printed as a report. In taking their history patients are asked whether they are allergic to any drugs, i.e. if there are any drugs they should not take. If the answer is yes, and one or more drugs are cited, then they are asked what happened the last time when they took the drug, i.e. what reaction occurred, so that it was diagnosed as an allergy. For example, an allergy diagnosis made by a doctor who told the patient after an adverse reaction that she was allergic to the drug and that she should no longer use it. Sometimes they state that they had an adverse reaction in their childhood, which is when they were told that they were allergic to the drug, i.e. they can't explain exactly what happened. The allergy data obtained are entered in the corresponding field, i.e. drug allergy field, which is then analyzed. Patients who responded that they should not take penicillin products because of the allergic reaction experienced after parenteral administration of penicillin were taken into consideration as those were considered confirmed allergic reactions.

Inclusion criteria: if a patient has experienced a reaction after receiving parenteral penicillin, and at another time in a separate event they experienced an adverse reaction to another drug, they were included in the study.

Exclusion criteria: if a patient received penicillin and another drug at the same time, then that patient was not included in the study. Oral penicillin preparations and their related adverse reactions were not taken into account. They were recorded separately when entering data about patients. When running queries a few patients showed up more than once. Their claims of having drug allergies were compared. If their answers to the question about drug allergies were consistent each time, only one entry was made and the rest were deleted. If, on separate occasions, their answers were inconsistent all the entries for those patients were deleted as we considered them unreliable.

In the end there were 242 patients left for analysis, accounting for $9.8 \%$ of the total number of patients examined. The data was then exported to an Excel spreadsheet, where the sort and count search was performed. Statistical testing of $\chi^{2}$ test contingency tables and descriptive statistics in SPSS 11 for Windows. 
In the end there were 242 patients left for analysis, accounting for $9.8 \%$ of the total number of patients examined. The data was then exported to an Excel spreadsheet, where the sort and count search was performed. Statistical testing of $\chi^{2}$ test contingency tables and descriptive statistics in SPSS 11 for Windows.

\section{Results:}

Of the 2481 patients, 242 stated they had experienced some adverse reactions to parenteral penicillin, which was diagnosed by a physician as an allergic event.

Of that number 82 patients did not know what happened. Of the 71 who were declared allergic to penicillin in their childhood, only 9 were able to explain what reaction exactly occurred.

Therefore, for the analysis we were left with 160 patients who were able to explain what exactly happened and they listed 204 adverse reactions in total.

Patients were aged between 18 and 85 years old. $X^{2}=49.64 \mathrm{sd}=17.243$.

There were 55 male patients, i.e. $34.4 \%$ and 104 female patients, i.e. $65 \%$, patients of unknown gender were $0.6 \% \quad \chi^{2}=16,685$ $\mathrm{p}<0,01.49$ of them were allergic to another drug besides penicillin, i.e $30.62 \%$.

Table 1 Reaction experienced after administration of parenteral penicillin

\begin{tabular}{|c|c|c|}
\hline Experienced reaction & $\begin{array}{c}\text { Num } \\
\text { ber }\end{array}$ & $\%$ \\
\hline Rash, hives, redness of skin, itchiness, blisters on skin & 64 & 31,37 \\
\hline Loss of consciousness & 31 & 15,2 \\
\hline $\begin{array}{l}\text { Eyelid swelling, face or mouth swelling, tongue swelling, } \\
\text { swelling of body or arms }\end{array}$ & 26 & 12,74 \\
\hline Dyspnea & 21 & 10,29 \\
\hline Buzzing or pulsing in ears & 11 & 5,39 \\
\hline Collapsing & 6 & 2,94 \\
\hline Blacked out/blurred vision & 5 & 2,45 \\
\hline Dizziness & 4 & 1,96 \\
\hline Coma & 4 & 1,96 \\
\hline Mouth distortion & 2 & 0,98 \\
\hline Vomiting & 2 & 0,98 \\
\hline Tingling of tongue & 2 & 0,98 \\
\hline Palpitations & 2 & 0,98 \\
\hline Tingling in hands & 2 & 0,98 \\
\hline Elevated BP & 2 & 0,98 \\
\hline $\begin{array}{l}\text { Occurring once: Wetting themselves, nausea, shock, drop in } \\
\text { blood pressure, pressure in the head, seizure, sinking feeling, } \\
\text { something stuck in the throat, feeling cold, foaming at the } \\
\text { mouth, hearing sounds, 'wave' going through the body, } \\
\text { twisted tongue, increased epilepsy, their child got pencililin, } \\
\text { so they reacted with an allergy, choling, was once allergic } \\
\text { but not anymore, seeing stars, a nosebleed }\end{array}$ & 18 & 8,82 \\
\hline Total & 204 & 99,98 \\
\hline $\mathrm{N}^{\circ}$ of patients & 160 & \\
\hline
\end{tabular}

Some patients have reported more than one adverse reaction. 


\section{Discussion:}

Out of 242 patients, 160 were able to explain what kind of reaction they had after drug administration. The group had an average age of 49.64 , with the majority of them being female and with most commonly reported reactions being skin reactions like rash, hives, redness, blisters or itchiness, then loss of consciousness, eyelid, face or mouth swelling, as well as swelling of the arms or hands. They experienced dyspnea, ringing or pulsing in the ears, then less frequently they reported fainting, blackouts, dizziness, coma, mouth distortion, vomiting,tongue tingling, heart palpitations etc. The limitation of our study is in the fact that our data was taken verbally from the patients who described in their own words the adverse reactions they experienced that were later diagnosed as penicillin allergy, i.e. we were not in the position to verify their selfreported allergies as we had no access to their medical records.

Depending on a study, the number of patients reporting penicillin allergy is ranging from $8-12 \%$ depending on the populations evaluated(6). In a study from Boston, USA, "again, the most commonly reported drug intolerances, in this somewhat older population, were to penicillins, with $12.8 \%$ reporting an "allergy"(7). In a study from France, $9.4 \%$ of patients stated they were allergic to penicillin(17). In $7-15 \%$ of children there is a suspected allergic/hypersensitivity (HS) reaction to drugs, especially antibiotics (18). In Great Britain, based on a study on medical records of 2.3 million of adult patients the prevalence to penicillin allergy is at $5.9 \%$, more frequently in older patients, females and patients with co-morbidities as stated by their GPs(14). In our study, that percentage is at about $10 \%$.
In the research from Macy E, Romano A, Khan D it is stated that "antibiotic allergy prevalence increases with increasing age and is more common in hospitalized populations and in populations that use more antibiotics"(19).

In the study by Macy et al there is a larger representation of females $9.46 \%$ as compared to males 5.93\%(1). "Antibiotic allergy incidence rates are sex dependent, higher in females than in males" (19). The most common allergic reactions were rash (37\%), unknown/undocumented (20.2\%), hives $\quad(18.9 \%), \quad$ swelling/angioedema $(11.8 \%)^{\prime \prime}(6)$. Most commonly exhibited adverse reactions to administration of parenteral penicillin are skin rashes and itchiness, dyspnea and wheezing, swelling of eyelids, face or mouth, tongue swelling or redness, fever or shivering, joint pains, sudden drop in blood pressure (8)

According to $\operatorname{CDC}(16)$, out of all adverse reactions that can be categorized as allergic reactions according to drug information sheets, in our study we had redness, itchiness, hives, rash, swelling of eyelids, face, mouth, tongue, dyspnea, loss of consciousness, fainting, blackout or blurred vision, nausea, vomiting, tingling of tongue, palpitations, hand tingling, seeing stars, shock, drop in BP, sinking feeling, numbness, tight throat feeling, Table number 1 . As many as 82 of our patients of the total of 242 , i.e. $33.9 \%$, state they are allergic to penicillin but are unable to list even one symptom of what happened in their allergic reaction. 71 patients of 242 , i.e. $29 \%$, state they have penicillin allergy since childhood. Other researchers also state this as a fact, i.e. that a large percentage of patients who are reporting penicillin allergy have had it since childhood (5). 
The most common allergic reaction is rash, as stated in multiple studies. "Overall, improved referral to an allergist will help to identify patients who have penicillin allergy requiring avoidance"(6). In the study by Branelec A et al, skin rash is present in $58.6 \%$ of cases and $13.1 \%$ have reported serious adverse reactions such as coma or urgent hospitalization with anaphylactic shock being the case in $8.8 \%(17)$. Only one of our patients reported having been in 'shock' even though conditions like unconsciousness, coma and shock account for $33.9 \%$ of total adverse reactions.

"Diagnosis of drug allergy is largely based on clinical history because diagnostic tests are limited. Most patients who are labelled as having penicillin allergy can tolerate penicillins after allergy evaluation"(20). Many patients report being allergic to penicillin, but only very few of them have clinically significant reactions(21). Even in our study we had somewhat lighter adverse reactions reported after administration of penicillin, i.e. skin rash, itchiness or redness of skin, dizziness, tongue numbness etc. Table number 1 .

In the study of Kusic et al it is stated that "the most common initial symptoms were rash(exanthema) and angioedema. None of the patients with self-reported allergic reaction to penicillin had positive in vitro tests. Total number of patients with positive in vivo tests is $2 / 81$ (2.5\%)"(13)."Something completely else, but clearly not an immunologically mediated reaction, such as a pharmacologic reaction, expected side effect, headache, yeast infection, gastrointestinal upset, viral exanthem, other benign reaction or association, fear, or some unknown reaction, account for the majority of penicillin "allergies" reported in the electronic health record (EHR), approximately $95 \%$ to
97\%"(1). In our study we had a good portion of such reactions. Table number 1 . Not all self-reported allergies are true drug allergies. Adverse reactions can be truly allergic but also pseudo-allergic such as: dizziness, palpitations, visual and hearing disturbances, change in consciousness, skin changes(8). Among the adverse reactions we have recorded and that fall under the pseudo-allergic procaine reaction or other immunological reaction cited in the drug information sheet or a neurotoxic reaction (8) are: dizziness, buzzing or pulsing in the ears, feeling of numbness in tongue and arms, heart palpitations, stiffness, mouth distortion, foaming at the mouth, seeing stars, palsy, hearing sounds, 'wave' going through the body, twisted tongue, increased epilepsy symptoms, etc. Table number 1 . These reactions are not listed in the drug information sheets but could be the result of Hoigne's syndrome, which occurs after intramuscular administration of penicillin $G$ procaine. Hoigne's syndrome manifests itself as severe psychomotor agitation with confusion, a sense of disintegration, depersonalization and derealization, a sense of change in body shape, visual and auditory hallucinations, panicked fear of death, changes in consciousness and epileptic seizure( 8$)$. Only one in 1543 patiens $(0.065 \%)$ with oral administration and one in 1030 $(0.097 \%)$ with parenteral penicillin associated administration were confirmed as cases of anaphylaxis(11), and only one of our patients stated that he experienced "shock", but several of them stated they wereunconscious which could indicate a serious reaction or perhaps even an anaphylaxis, Table number 1. "Most patients who report penicillin allergy can tolerate penicillins without having an adverse or hypersensitivity reaction. Unfortunately, most patients do not undergo penicillin allergy testing, which 
leads to use of alternative antibiotics that result in increased morbidity. This increased morbidity leads to a significant detrimental economic effect on health care. In patients with negative test results, most recurrent reactions are benign rashes. There is always a fear that an anaphylactic reaction would occur on re-exposure to a penicillin; however, multiple studies have found that this is an extremely rare occurrence"'(22). Although anaphylaxis is a rare occurrence, it is not possible to remove responsibility for administering penicillin to patients who indicate that they are allergic to penicillin.

Penicillin allergy may be a serious adverse reaction that affects the possibility of antibacterial treatment. Although it is often recorded in medical records, only a minority of patients with a recorded penicillin allergy actually have a confirmed allergy. "The term 'allergy' may be incorrectly applied to adverse reactions that do not have an immunological basis and inappropriate labelling of penicillin allergy can lead to the unnecessary avoidance of penicillins and other betalactam antibacterials"(23). Given the increasing resistance to antibiotics, and that penicillin remains a highly effective medicine in the fight against many infections, the fact that the number of reported allergies is more than 10 times higher than the number of actual allergies is a serious health problem(16).

Most children who report an allergy to a multi-class drug or a family of antibiotics are not allergic to these drugs. In these children, one would think of allergic or nonallergic intolerance or hypersensitivity to other drugs, often given in addition to antibiotics (non-opioid analgesics, antipyretics and non-steroidal anti-inflammatory drugs in particular)(18).
"Verification of the penicillin allergy in hospitalized patients might restrict the use of reserve antibiotics and improve patient outcome"(15).

"Establishing true penicillin allergy status (e.g. oral challenge testing) would allow more people to be prescribed first-line antibiotics, potentially improving health outcomes"(14). "Seven to $15 \%$ of children report suspected allergic/hypersensitivity (HS) reactions to drugs, antibiotics especially, but studies based on clinical history, skin tests (ST) and drug challenge/ provocation tests (DPT) have shown that only $10-15 \%$ of these children were truly allergic, except for the children reporting immediate and/or severe reactions"(18).

About $10 \%$ of the population reports an allergy to penicillin, but after testing, up to $90 \%$ of these patients do not have an allergy to penicillin(24)

"Antibiotics are the commonest cause of life-threatening immune-mediated drug reactions and many antibiotic reactions documented as allergies were unknown or not remembered by the patient. Antibiotic allergy labels result in displacement of firstline therapies for antibiotic prophylaxis and treatment which is associated with increased use of broad-spectrum and non- $\beta$ lactam antibiotics, which results in increased adverse events and antibiotic resistance. Most patients labelled as allergic to penicillins are not allergic when appropriately stratified for risk, tested, and rechallenged"(25). "An unconfirmed penicillin "allergy" is a significant health risk and testing can significantly lower this risk" (7).

In the study of Kusic et al "adverse effects to penicillin were reported by $70 / 81$ $(86.4 \%)$ tested patients. None of the 70 pa- 
tients with self-reported allergic reaction to penicillin had positive in vitro tests. Total number of patients with positive in vivo tests is $2 / 81(2.5 \%) "(13)$.

Penicillin allergy testing is an intervention that through the analysis of assumed sensitivity is a less expensive option and saves money(12).

Establishing the true status of penicillin allergy will allow more people to be prescribed the first line of antibiotics and possibly improve patient health outcomes.

The best method for determining IgEmediated penicillin allergy is a skin test (13). Skin testing is associated with frequent false positives and false negatives(1).

The negative predictive value of the skin test is more than 95\%, and when checked with a single oral dose of the drug it is close to $100 \%$ while the positive predictive value is between $40 \%$ and $100 \%$ (16). Vićentijević states that in $23 \%$ of patients, drug allergy has been further tested and confirmed by analysis(9).

However, only $6 \%$ of patients who report an allergy have a confirmed report from an allergy specialist. All in all, a confirmed consultation with an allergist helps to detect patients with penicillin allergy and require drug avoidance"(6). Still, the problem is that there are millions of patients with the need to have their penicillin allergy either confirmed or dismissed.

Doctors and patients who should be given penicillin are in favour of testing, although all those who have been labeled as allergic are not convinced about the benefit of the study.

The problem with allergy to penicillin and other drugs could also be in the legal regula- tions, i.e. in the actual reporting process. In order to report an allergy to the drug, it is sufficient that a doctor suspects it based on the adverse reaction.

\section{Conclusion:}

The most common reactions after administration of parenteral penicillin are cutaneous manifestations, loss of consciousness, swelling of the tongue and face, dyspnea. About $40 \%$ of what our patients report is a serious reaction like loss of consciousness and dyspnea. One portion of all reported reactions could be classified as nonallergic reactions or adverse drug reactions. 
Marta S Ljubisavljević, Slavoljub R Živanović. Self-reported allergy to parenterally administered penicillin $\mathrm{ABC}$ časopis urgentne medicine 2020:20:(3):43-53

01-8877-12-004.pdf

9. Vićentijević-Radosavljević SS. Drug allergy and medical records in Health center "Zvezdara." Opšta Med. 2017;23(34):53-8.

10. Dmitrović RR, Živanović SR. Patients' claims regarding drug allergies. Hosp Pharmacol - Int Multidiscip J. 2020;7 (1):875-82.

11. Liang EH, Chen LH, Macy E. Adverse Reactions Associated with Penicillins, Carbapenems, Monobactams, and Clindamycin: A Retrospective Population-based Study. J Allergy Clin Immunol Pract. 2019 Dec 9;

12. Au LYC, Siu AM, Yamamoto LG. Cost and Risk Analysis of Lifelong Penicillin Allergy. Clin Pediatr (Phila). 2019 Oct;58(11-12):1309-14.

13. Kusić N, Tomić-Spirić V. Penicillin allergy evaluation: Experience from Clinic of Allergology and Immunology, Clinical Center of Serbia. Med Podml. 2018;69

(1):45-50

14. West RM, Smith CJ, Pavitt SH, Butler CC, Howard P, Bates C, et al.

"Warning: allergic to penicillin": association between penicillin allergy status in 2.3 million NHS general practice electronic health records, antibiotic prescribing and health outcomes. J Antimicrob Chemother. 2019 Jul 1;74(7):2075-82.

15. van Dijk SM, Gardarsdottir H, Wassenberg MWM, Oosterheert JJ, de Groot $\mathrm{MCH}$, Rockmann H. The High Impact of Penicillin Allergy Registration in Hospitalized Patients. J Allergy Clin Immunol Pract. 2016 Oct;4(5):926-31.

16. Evaluation and Diagnosis of Penicil- 
lin Allergy for Healthcare Professionals | Community $\mid$ Antibiotic Use $\mid$ CDC [Internet]. 2019 [cited 2020 Feb 6]. Available from: https://www.cdc.gov/antibioticuse/community/for-hcp/Penicillin-

Allergy.html

17. Branellec A, Thomas M, Fain O, Kettaneh A, Stirnemann J, Letellier E. [Frequency of self-reported penicillin allergy in the area of Seine-Saint-Denis (France)]. Rev Med Interne. 2008 Apr;29 (4):271-6.

18. Ponvert C. Les réactions d'hypersensibilité aux médicaments anti-infectieux. Rev Fr Allergol [Internet]. 2020 Feb 11 [cited 2020 Mar 21]; Available from: http:// www.sciencedirect.com/science/article/pii/ S1877032020300075

19. Macy E, Romano A, Khan D. Practical Management of Antibiotic Hypersensitivity in 2017. J Allergy Clin Immunol Pract. 2017 Jun;5(3):577-86.

20. Abrams EM, Khan DA. Diagnosing and managing drug allergy. CMAJ Can Med Assoc J J Assoc Medicale Can. 2018 30;190 (17):E532-8.

21. Shenoy ES, Macy E, Rowe T, Blumenthal KG. Evaluation and Management of Penicillin Allergy: A Review. JAMA. 2019 Jan 15;321(2):188-99.

22. Macy E, Vyles D. Who needs penicillin allergy testing? Ann Allergy Asthma Immunol. 2018 Nov 1;121(5):523-9.

23. Penicillin allergy-getting the label right. Drug Ther Bull. 2017 Mar;55(3):33-6.

24. St NB. Drug Allergy: An Updated Practice Parameter. Ann ALLERGY. 2010;105:78.

25. Blumenthal KG, Peter JG, Trubiano
JA, Phillips EJ. Antibiotic allergy. Lancet Lond Engl. 2019 12;393(10167):183-98.

26. Wanat $\mathrm{M}$, Anthierens S, Butler CC, Savic L, Savic S, Pavitt SH, et al. Patient and Primary Care Physician Perceptions of Penicillin Allergy Testing and Subsequent Use of Penicillin-Containing Antibiotics: A Qualitative Study. J Allergy Clin Immunol Pract. 2019 Aug;7(6):1888-1893.e1.
Primljen - Received 16.11.2020.

Prihvaćen-Accepted 17.12. 2020. 
Marta S Ljubisavljević ${ }^{1}$

Slavoljub R Živanović ${ }^{2}$

${ }^{1}$ Dom zdravlja "Milutin Ivković" Palilula, Belgrade

${ }^{2}$ Gradski zavod za hitnu medicinsku pomoć Beograd Srbija

\section{Samoprijavljene alergije na parenteralno dati penicilin}

Uvod: Penicilin i penicilinski preparati su u svakodnevnoj medicinskoj praksi. Najčešća prijavljena reakcija na lek je na penicilin. Nove Penicilinske alergije su češće posle primene parenteralnog nego oralnog puta davanja. Kod pacijenata koji su alergični na penicilin, se češće primenjuju antibiotici širokog spektra, a terapija je skuplja. Alergije na penicilin su imunološki posredovane.

Cilj rada je bio: Pokazati tvrdnje pacijenata koji su izjavili da su alergični na penicilin, kakvu su reakciju doživeli posle parenteralnog dobijanja penicilina.

Metodologija: Retrospektivna studija rada jednog lekara u GZHMP Beograd u periodu 2017 do 2018 godine na 2481 pacijenata.

Rezultati: Pronađeno je 242 pacijenta koji su dali podatak da su alergični na peniclin, a 160 je znalo da kaže šta se desilo posle dobijanja parenteralnog penicilina. Ispitivana grupa je starosti od 18-85 godina, prosečne starosti 49,64 +- 17,24 godina, dok je $65 \%$ osoba bilo ženskog pola. Najčešće prijavljene reakcije su bile ospe, crvenilo I svrab po koži, potom gubitak svesti, a zatim otok lica usana jezika kože tela ili ruku. Ozbiljne reakcije su se javile u oko $40 \%$ slučajeva.

Zaključak: Veliki je procenat samoprijavljene alergije na penicilin, a mali je broj onih koji su doživeli ozbiljne reakcije: otok, bez svesti gušenje, koma ili šok.

Ključne reči: Primarna zdravstvena zaštita, alergije na penicilin, parenteralna primena, hitna medicinska pomoć. 